The Mongoose in Jamaica.

IN Jordan and Kellogg's admirable little book, "Animal Life," we read (p. 293):- "The mongoose, a weasel-like creature, was introduced from India into Jamaica to kill rats and mice. It killed also the lizards, and thus produced a plague of fleas, an insect which the lizards kept in check."

As it is evident from this and other signs that the Jamaica mongoose is to lecome celebrated-in text-books, it seems worth while to call attention to the facts actually known about it. An excellent summary showing the status of affairs in 1896 was written by Dr. J. E. Duerden and published in the Journal of the Institute of Jamaica, vol. ii. pp. 288-29I. In the same volume, p. 47I, are further notes on the same subject.

The creatures which increased and became a pest were ticks, not fleas. The present writer can testify to their excessive abundance in the island in 1892 and 1893 . The species were various, and were examined by Marx and Neumann, whose determinations appear in Journ. Inist. Jamaica, vol. i. p. 380 , and vol ii. p. 470 . It will be noted that the common species are not confined to Jamaica, and, in fact, have probably, most of them, been introduced from elsewhere. Hence it is quite possible that their abundance is in large part due to their recent introduction.

T. D. A. Cockerell.

East Las Vegas, New Mexico, U.S.A., January 17.

\section{Thermochemical Relations.}

LET us consider gr. 2 of $\mathrm{H}$, gr. 16 of $\mathrm{O}$ and gr, $7 \mathrm{r}$ of $\mathrm{Cl}$, namely, volumes 2 of $\mathrm{H}, \mathrm{I}$ of $\mathrm{O}, 2$ of $\mathrm{Cl}$. We can combine these corps two by two to form the three following compounds :-

$$
\text { gr. } 87 \text { of } \mathrm{Cl}_{2} \mathrm{O} \quad \text { gr. } 18 \text { of } \mathrm{H}_{2} \mathrm{O} \quad \text { gr. } 73 \text { of } \mathrm{HCl}
$$

that occupy respectively $2,2,4$ volumes.

The heats of combination are respectively :-

$$
-\mathrm{I} 4+58
$$

between which is the simple relation

$$
-14+5^{8}=44 \text {. }
$$

In another example, where one of the components is solid but remains the same ratio between the volumes of the compounds, we have again the same relation between the combining heats. In fact, with

$$
\text { gr. } 2 \text { of } \mathrm{C} \quad \text { gr. } 4 \text { of } \mathrm{H} \quad \text { gr. } 32 \text { of } \mathrm{O}
$$

we can form

$$
\text { gr. } 16 \text { of } \mathrm{CH}_{4} \quad \text { gr. } 44 \text { of } \mathrm{CO}_{2} \quad \text { gr. } 36 \text { of } \mathrm{H}_{2} \mathrm{O}
$$

which occupy respectively 2,2 and 4 volumes.

The cumbining heats are respectively

$$
+19+97+116,
$$

and we find

$$
19+97=116 .
$$

Is it a casual coincidence or a law ?

Spezia (Italy), Nov. I4, 1900.

Carlo Del lungo.

\section{Direction of spirals in Horns.}

ABOU' $\mathrm{Mr}$. Blanford's interesting remarks on my letter in NATURE for January Io, I should like to answer that, far from thinking the matter "simple,"I find that the facts are nowhere recorded and certainly are not generally known to naturalists or sportsmen. This is why I attempted to formulate rules.

The rule that in antelopes the direction of the spiral is "crossed" (i.e., the right horn is sinistral, and the left horn is dextrorsal) holds good in the Koodoos, Elands, Indian antelope, Bushbuck, Impalla, and Speke's antelope (noted by me in the Lancet, January I, I898, "On Spiral Growth").

In oxen the horns are "homonymous" in direction-the right horn twists to the right, the left horn to the left-and many horns show a good spiral. I may mention the Cape buffalo, musk ox, domestic ox, also the Urus and the Chartley bull. The only exception to the rule in the Cambridge Museum is an Indian buffalo.

In the sheep, the direction of the spiral is "homonymous," as in the ox, except Ovis orientalis and Ovis nahura.

In the goats, Mr. Blanford, in his " Fauna of British India, Mammalia," notes that there is a difference berween the wild and the tame goats in the following passage: "But the spiral in tame goats is almost always in the reverse direction to that NO. I632, vOL. 63 ] found in Markhor, the anterior ridge in the tame animals turning inwards at first in each horn.

"I have, however, seen exceptions; there is one from Nepal in the British Museum."

After searching many books on horns (including $\mathrm{Mr}$. Lyddeker's), this is the only note on the direction of spirals that I can discover. The causes of the spirals, and of the differences in directions, are still to seek. Cambridge.

GEORge Wherry.

\section{SOME DISPUTED POINTS IN ZOOLOGICAL NO.MENCLATURE.}

$\triangle M O N G$ that large section of the general public who are interested, to a greater or less degree, in natural history there is a widely spread impression that, as most of the more familiar animals have a single, definite and indisputable popular designation, so every known species in the animal kingdom has one proper technical title by which it is known throughout the zoological world; and consequently that when they have once made themselves acquainted with this title, there is no more to be said on the subject. To a certain limited extent (some authorities would, perhaps, be inclined to say invariably) there is no doubt that this idea is perfectly well founded. But, in the first place, there is a difference of opinion among zoologists as to the limits of genera, and whereas one worker would retain a species in the genus in which it was placed by its original describer, another would regard it as entitled to represent a genus by itself. Thus one great element of diversity in nomenclature is introduced.

But there are also a very large number of cases in which an equal diversity of view obtains as to the proper specific title of an animal. And the inquirer will not be long in ascertaining that, in place of unanimity, an almost chaotic state of uncertainty prevails as to what should be the proper binomial designation of a large percentage of animals. Consequently, in place of being one of the easiest, the question of nomenclature is, in many cases, one of the most difficult; and the unhappy inquirer will too often find that he receives a different answer from almost every authority to whom he applies. Nor is this all, for whereas a considerable number of systematic zoologists are agreed in some measure upon certain general principles of nomenclature, their opinions are not shared by many of the workers in palæontology, morphology and geographical distribution, who adhere to more antiquated views on these questions.

The reasons for this regrettable and unfortunate state of affairs are many and varied. And as a crisis on the question is likely to arise in the near future, if indeed it be not already upon us, the editor is of opinion that there are many readers of NATURE who would like to be informed of some of the chief points at issue, and of the more important suggestions which have been made towards arriving at a settlement. It will consequently be understood that the present article has been written solely from this point of view, and that it makes no pretence to discuss all the questions, or to enter into details interesting to zoologists alone.

One of the points at issue-and it is one of the most important-is what we may term the theory of the sacredness and immutability of the specific name. Soon after Linnæus had completed the last edition of the "Systema Natura" published under his own personal supervision, it became apparent that a large number of the animals named by him could nolonger be permitted to remain in the genera in which they were included in that work. The giraffe, for example, which had been named Cervus camelopardalis by the Swedish naturalist, was certainly entitled to generic distinction from the deer. At this date the idea of the "sacredness" of the species name had not yet originated, and Gmelin, in his edition of the 